\title{
276
}

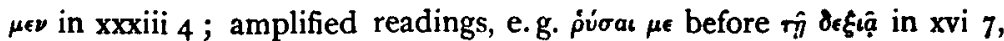

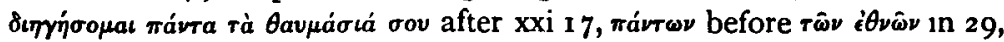

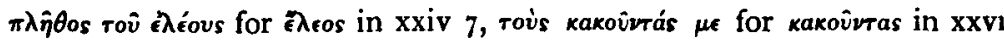

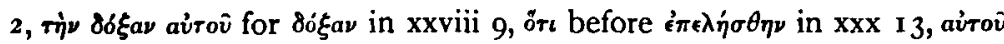

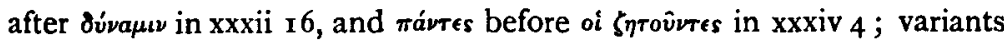

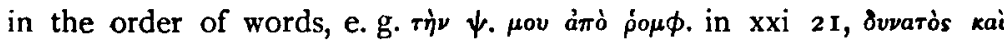
xparatós in xxiii 8, and $\dot{\eta} \sigma a ́ \rho \xi \mu \nu ~ a ̀ v e ́ \theta a \lambda \epsilon \nu$ in xxvii 7 . It would seem therefore that the Sahidic represents the complete Greek text of which $\mathrm{U}$ contains fragments. (4) The Titles are noticeable; see e.g. ii, xxxiii, lix, lxiv, lxx, lxxx, cxiii, cxxxv.

F. E. Brightman.

\section{ON EARLY INSERTIONS IN THE THIRD BOOK OF ST. CYPRIAN'S TESTIMONIA.}

Among a number of more or less doubtful passages whose claim to a place in the text of St. Cyprian's Testimonia wll have to be weighed by future editors, a group of three pieces in the third Book stands first in order of importance :-

(r) In Test. iii 20 'Item in Deuteronomio ... nominis mei' (p. 134, $15 \ldots$ p. $138,2 \mathrm{I}$ in Hartel's edition);

(2) In Test. iii 29 'Item in Baruch... odibiles alieno' (p. r 43, 2-I4);

(3) In Test. iii 59 'Item in Hieremia ... ascendet' (p. $161,8 \ldots$ p. 163,26$)$.

These pieces were first printed by Baluze, who found them in two MSS, his 'codex [Andegavensis] S. Albini,' and his 'codex Atrebatensis S. Eligii '.' Of Hartel's MSS the 'codex Wirceburgensis' (W) is the only one which has them. Their common history, and certain internal affinities, leave little room for doubt that the three insertions were made by one and the same hand.

The following passages of Scripture are quoted in the insertions :-

Deut. iv ro

Isa. xlvi $1,2,5-7$

Jer. ii $12,13,19,20,27$

" X 2-5, 9, II $(=x$ 2-II in LXX)

$" x \times x 131-34,37$

" xxxii 37-4I

", li $15-18$ (= xxviii $15-18$ in LXX)
Test. iii 20, p. 134, 15.

$$
\begin{array}{ll}
" & 59, \text { p. } 162,9 . \\
" & 59, \text { p. I61, I } 9 . \\
" & 59, \text { p. I61 } 8 . \\
" & 20, \text { p. I } 34,18 . \\
" & 20, \text { p. I } 35,11 . \\
" & 59, \text { p. I62, I } 9 .
\end{array}
$$

1 Cf. Baluze's notes on Test. $1 \mathrm{ii} 20$ and Test. ini 29. He does not name his authonties for the interpolation in Test. ni 59, but the 'codex S. Albini,' which is now in the municipal library of Angers (MS 140), contains the piece. I have not yet succeeded in finding any trace of the 'codex S. Eligii.' 
'Item in Baruch ...' (from an unknown work) Test. iii 29, p. 143, 2.

Dan. iii $37-4^{2}$

" vi $23^{-27}$

" xiii $I-3$

Micah vi 6-9

, vii $14-18$

Nahum i 5-7

Hab. iii 2 (in $W$ and the Quirinian fragment)

Haggai i 12

Mal. ii 5

Apoc. ix $13^{-2} 1$

"xi $16-18$

, $\quad$ xiv 6,7

" xiv 9-I I

, xv 2-4

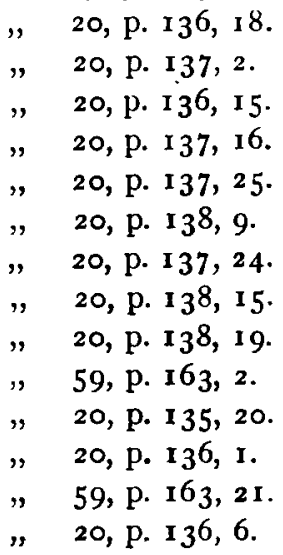

The three additional pieces, taken together, are equivalent to some seven pages of Hartel's text ; and in the case of the prophet Jeremiah the verses quoted in them constitute more than one-third of the total number of verses quoted in St. Cyprian's writings. In view, therefore, of the unique importance of St. Cyprian's citations from Scripture, it is most desirable to find out, if possible, whether or no the additional citations rest on his authority or even are taken from the version which he used.

I begin with the external evidence.

I. A great part of the additional piece in Test. iii 20 occurs in the fifth-century fragment discovered $\cdot$ in 1894 by Dr. Mercati in the Quirinian Library at Brescia ${ }^{3}$. The MS in its complete state certainly had the whole of this addition, and we may farly suppose that, like the closely related $W$ and the 'codex S. Albin ' or Angers MS, it contained the others also. The additions, therefore, were made before the end of the fifth century.

2. On the other hand, the fact that these additions have only been found in four MSS (if the Quirinian may be included) proves conclusively that they were not in the Testimonia as originally put in curculation by St. Cyprian; for had that been the case, it is impossible to account for their removal from the main stream of transmission. There is, however, nothing intrinsically unreasonable in the supposition that St. Cyprian made these insertions in a late copy, when the work had already passed by multiplication beyond the sphere of his control.

1 The text of the fragment is printed and critically examined by Mercati in his important work $D^{\prime}$ alcunt nuovi sussidi per la critica del testo di $S$. Cipnano, pp. I f., 44 f. All my subsequent references to Mercatı will be to this volume. 
The idea of a second edition of ancient works, revised by the author, is quite natural in itself, and is being allowed its full weight in the discussions of modern criticism. Thus Dr. Blass's view that St. Luke issued two recensions of the Acts and of the third Gospel has certainly met with respectful attention, and (in the case of the Acts at least) with a good deal of support ; while in the sphere of classical literature it is interesting to notice that Dr. Sandys is disposed to attribute to Demosthenes himself both of the forms in which the Third Philippic has come down to us. Yet in the case before us the supposition that these additions in the Testimonia are due to revision by St. Cyprian himself cannot be said to rise above the level of a bare possibulity, for if they had really been made by St. Cyprian, it is difficult to see how they could have farled to secure a wider currency.

When we pass to the internal evidence, it does not appear that anything can be gained for our purpose from a consideration of the subjectmatter of these additions. There is no indication that the selection of the texts contained in them was determined by any specific tendency or point, such as a particular individual or party might be expected to emphasize. Nor does the want of order in the arrangement of the passages tell against the Cyprianic origin of the insertions. If the argument drawn from want of order has any force at all, it applies in a much wider field than the pieces under consideration occupy.

With regard to the books quoted there is an unmistakable similarity between the set of passages inserted in Test. iii 20 and the set inserted in Test. iii 59. In both cases the Apocalypse is the only New Testament book from which citations are made; in both cases, with the exception of a single verse from Deuteronomy (iv 10) in Test. iii 20 , all the Old Testament passages are taken from the prophetical books; and in both cases Jeremiah is the prophet most prominently quoted. But these facts, while they tend to show that the two sets of passages were selected by one and the same person, afford us no hint as to who that person was ${ }^{1}$. The passage inserted in Test. ini 29 , which is introduced with the words 'In Baruch,' but which is not found in any known work bearing the name of Baruch ${ }^{2}$, is the only one which has

1 [It is perhaps worth noting that, as Dom Morn has recently pointed out (Revue d'histoire et de litterature relggeuses $\mathrm{V}$ is $\mathrm{pp} .148,15^{\circ}$ ), the phrase Hueremas receptissimus prophetarum occurs in three writings of the fourth and fifth centuries, the De fide onthodoxa of Gregory of Elvira (or Phoebadius of Agen), the De Trintate of pseudo-Vigilius, and the newly-discovered Tractatus Ongenis. One is tempted to suspect some local connexion between the employment of this phrase and the unusually large use of the same prophet in these insertions in the Testimonia. C H.T.]

2 Dr. Mercati's statement (p. 2) that the quotation is taken from 'the apocryphal Apocalypse of Baruch,' even when considered in the light of his subsequent 
so much as an appearance of significance in this connexion, and even this after all tells us nothing. Mercati, indeed, seems to think that the quotation of this passage as Scripture justifies or at least suggests the conclusion that the insertions were made at an early date, i e. not later than the fourth century. 'Conosciamo bene il canone biblico della Chiesa Africana alla fine del secolo iv '.' But the argument condensed in these words will not bear scrutiny. Our knowledge of the Biblical Canon of the African Church at the end of the fourth century rests mainly on the list of the sacred books drawn up at the Council of Carthage (397). In that list Baruch is not mentioned at all : no one doubts that it was included under the name of Jeremiah, but at least no indication is given as to how much or how little of the Baruch literature was accepted. Modern discoveries are showing how varied that literature was ', and if the quotations of the African fathers prove the wide circulation and general acceptance of all that now stands under the name of Baruch in the Vulgate, there is nothing which renders improbable the supposition that other writings attributed to Baruch had some (more limited) circulation even among the orthodox. We may go further and say that even if the book from which the quotation in Test. 1i1 29 is made had been expressly excluded from the Canon by the Council of Carthage, we should not be reduced to the necessity of choosing between the alternatives of assigning an early date for these insertions or of attributing them to a non-Catholic interpolator. It would betoken a fallure to make sufficient allowance for the uncertainties of human conduct, were we to argue too confidently from a conciliar pronouncement, however precise, to the action of individual writers, however orthodox. St. Augustine himself is

explanation, is somewhat misleading We simply do not know the exact title of the book from which the passage is taken. The passage does not occur in the Syriac Apocalypse of Baruch, discovered and edited by Ceriani ( 1871 ), nor in the Greek Apocalypse of Baruch, discovered by Dom Butler in Cod Mus. Brit. Add 10,073, and edited by Mr. M. R. James in Texts and Studtes (vol. v, no. 1, 1897). The Greek Apocalypse, whose discovery has escaped Mercatı (cf. p. 3, n. I ' L' apocalisse in greco non si conserva pru'), proves to be a distinct work from the Syriac, and the passage quoted in the Testimona seems to be nearer in thought to the Syriac than to the Greek. Mr. R. H. Charles, in the introduction to his translation of the Syriac Apocalypse (p. xix), goes so far as to say that the book from which the quotation was taken 'is clearly based on (the Syriac) Apocalypse'; but (if there be any direct connexion) it seems more hikely that the passages from the Syriac Apocalypse which he co-ordinates with the quotation in Test. un 29, are a 'workıng up' of the ideas contaned in the latter. The restraint and solidity which charactenze the quotation in Test. 11129 cause it to have a greater resemblance to the prophetic style of $O$. T. than to the exaggerated language of the later Apocalypses.

1 Mercati, p. 4.

2 Cf. James in Texts and Studres, vol. v, no. i, p. hin f. 
found to quote as Scripture, parallel with a citation from the third Gospel, a passage which has not as yet been discovered in any version of any canonical book ${ }^{1}$.

Thus it is clear that our chief hope of getting light as to the origin of these insertions is to test the character of the version from which the passages are taken. Mercati states this with excellent clearness ${ }^{2}$, and ends his examination, not indeed by definitely acknowledging the genuineness of the disputed pieces (it would be obviously impossible to prove the genuineness by this method alone), but by expressing his belief that the qualities of the Scripture version used in them are quite in keeping with Cyprianic authorship, or at least imply an African and very ancient origin ${ }^{3}$.

But Mercati only discusses the Old Testament quotations, and confines himself for the most part to those which occur in the Quirinian fragment. By enlarging the range of inquiry, it is possible, I think, to prove conclusively that the insertions were not made by St. Cyprian, and that the citations contained in them cannot safely be considered to represent the old African version as he knew and used it.

I. Of the five passages from the Apocalypse which occur in these insertions, two (Apoc. xiv 6, 7; Apoc. xiv 9-II) are found in other parts of St. Cyprian's writings ; and fortunately one of the passages occurs in the addition to Test. iil 20 , and the other in the addition to Test. iii 59, so that for the Apocalypse we have a direct standard of comparison in each of the long insertions. The following is the text of Apoc. xiv 6, 7 as given in the addition to Test. iii 20 , and in Ad Fortunat. 2. In all the passages cited for comparison, I adhere to Hartel's text, even where I believe it to be wrong; his symbols are also used in the critical notes.

Apoc. xiv 6, 7 .

Ad Fortunat. 2, p. 323, 3 .

6 Et uidi alium angelum uolantem medio' caelo,

habentem euangelium aeternum ut adnuntiaret super terram

per $^{2}$ omnes nationes et tribus

1 in medıo $\mathrm{W}^{\prime} \mathrm{M} v$.

2 et super $v$.
Test. iii 20 (insertion), p. 1 36, I

6 Et uidi alium angelum uolantem medio caelo ${ }^{1}$, habentem euangelium perenne, euangelizare sedentibus super terram et in omnes nationes et tribus ' per medium caelum $v$.

${ }^{1}$ Enarr. in Ps. cis $\$ 12$ : 'Mendicus te quaerit, iustum tu quaere. De alıo enım dictum est, Omni petent te da (Lc. vi 30 ): et de alio dictum est, Desudet elecmosyna 'n manu tua, donec inuentas iustum, cut eam tradas.' Cf. also Enarr. in Ps. cui (Serm. 3) § 10, and Enari. in Ps. cxlvi $\$$ i7. 'p. 6r. 3 p. $64 \mathrm{f}$. 
Ad Fortunat. 2, p. $323,3$.

et linguas et populos ',

7 dicentem uoce magna,

Metuite potius Deum ${ }^{2}$

et date illi claritatem,

quoniam uenit

hora iudicii eius,

et adorate eum qui fecit

caelum et terram et ${ }^{\mathbf{s}}$ mare

et omnia quae in eis sunt.

1 et populos] om. W'.

2 dn̄m M, dñi R.

- et] om B.
Test. ili 20 (insertion), p. $136,1$.

et linguas et populos,

7 dicentem uoce ${ }^{1}$ magna, Timete Deum

et date ei honorem, quonım uenit hora iudicis eius, et adorate eum qui fecit caelum et terram et mare

et fontes aquarum.

dicens in uoce $\mathbf{W}$.

The other passage, Apoc. xiv 9-II, is quoted three times by St. Cyprian in undisputed places. The close agreement of these among themselves and their striking divergence from the text of the same passage in Test. iii 59 (addit.) appear at once when the quotations are placed side by side :-

Apoc. xiv 9-I I.

Ad Fortunat. 3, p. Ep. 58, 7, p. 663, 5. Ep. 65, 1, p. 722, 17. Test. iii 59 (inser$3^{2} 4,4$. tion), p. 163,21

9 Et tertius angelus secutus est eos dicens in uoce magna,

9 Si quis adorat
bestiam et
imaginem ejus
et accipit
notam
in fronte sua
et in ${ }^{1}$ manu,

10 bibet et ipse de uno irae Dei mixto in poculo irae eius et punietur igne et sulphure sub oculıs

9 Sı quis adorat ${ }^{1}$
bestıam et
ımaginem eius
et accipıt ${ }^{2}$
notam
in fronte sua
et in manu,

ro bibet et ipse de uino irae Des mixto in poculo irae elus et punietur igne et sulphure sub oculis
10 bibet et ipse de uino irae Dei mixto in poculo irae eius et punietur igne et sulphure sub oculis
Si quis adorat bestiam et sımulacrum eius, et accepit inscriptionem in fronte sua aut super ma- num suam, Io is ${ }^{1}$ bibet $^{2}$ de uino irae eius

\section{et punietur igne et sulphure} sub oculis sanctorumangelorum sanctorum angelorum sanctorum angelorum angelorum sanctorum et sub oculıs agni ; et sub oculıs agnı '; et sub oculis agni ; et sub oculis agni :

\footnotetext{
s aut in $v$.

1 adorabit $\mathbf{R}$.

2 accipiet $B$, accipj*t $M$, accipit at $Q$

s add. sua $M$.

- oculj sc̄i agnı B.
}

J adoret $\mathbf{C}^{\mathbf{1}}$.
1 hic $v$.
abet... elus et om. W.




\section{THE JOURNAL OF THEOLOGICAL STUDIES}

\begin{tabular}{|c|c|c|c|}
\hline $\begin{array}{c}\text { Ad Fortunat. } 3, \mathrm{p} . \\
3^{2} 4,4\end{array}$ & $E p .58,7$, p. $663,5$. & $E_{p .65}$, I, p. 722, I7. & $\begin{array}{c}\text { Test. iii } 59 \text { (inser- } \\
\text { tion), p. } 163,21 .\end{array}$ \\
\hline $\begin{array}{l}\text { I I et fumus } \\
\text { de tormentis eorum } \\
\text { in saecula } \\
\text { saeculorum } \\
\text { ascendet ' } \text {; } \\
\text { nec habebunt } \\
\text { requiem } \\
\text { die et nocte } \\
\text { quicumque adorant } \\
\text { bestiam } \\
\text { et Imaginem eius. }\end{array}$ & $\begin{array}{c}\text { I I et fumus } \\
\text { de tormentis eorum } \\
\text { in saecula } \\
\text { saeculorum } \\
\text { ascendet '; } \\
\text { nec habebunt } \\
\text { requiem } \\
\text { die ac nocte } \\
\text { quicumque adorat } \\
\text { bestiam } \\
\text { et imaginem elus. }\end{array}$ & $\begin{array}{l}\text { I I et fumus } \\
\text { tormentorum ' } \\
\text { in saecula } \\
\text { saeculorum } \\
\text { ascendet }{ }^{2} \text {; } \\
\text { nec habebunt } \\
\text { requiem } \\
\text { die et nocte } \\
\text { qui adorant } \\
\text { bestiam } \\
\text { et imaginem eius. }\end{array}$ & $\begin{array}{l}\text { II et fumus } \\
\text { tormentorum eorum } \\
\text { in saecula } \\
\text { saeculorum } \\
\text { ascendet }{ }^{1}\end{array}$ \\
\hline $\begin{array}{l}1 \text { ascendit } R \text {, as- } \\
\text { cendet in S. } \mathrm{s} \text { B. }\end{array}$ & ${ }^{1}$ ascendet in s.s. Pv. & $\begin{array}{l}\text { 'tormentoP, de tor- } \\
\text { mentis eorum } \mathrm{CR} v \text {. } \\
2 \text { ascendet in S.s. P. } \\
\text { ascendent } \mathrm{L} Q\end{array}$ & 'ascendit W. \\
\hline
\end{tabular}

The evidence of the Cyprianic MSS for the text of these citations as found in $A d$ Fortunat. 2 and 3 is still further strengthened by the agreement of Firmicus Maternus, who appropriates from St. Cyprian all the citations which occur in these chapters of Ad Fortunatum ${ }^{1}$. There is then no room for doubt as to the text of these passages as they stood in St. Cyprian's version. Nor is it possible to mistake the significance of the differences which exist between the Cyprianic form and the form found in the insertions. St. Cyprian's exactness in quoting Scripture is attested by his consistency ; and if his consistency has been somewhat obscured in the past generation by the unfortunate preference which Hartel gave to the altered text of $\mathrm{A}$ in the Testimonia, it is now too fully recognised to stand in need of proof. In the course of the twenty-eight verses quoted by St. Cyprian from the Apocalypse on more than one occasion, there is in fact only one place ${ }^{2}$ in which the evidence of the MSS requires us to accept notably different readings in parallel passages.

In the case of the three remaining quotations from the Apocalypse (ix I3-2 I, xi I 6-I 8, xv 2-4) we cannot directly confront the interpolator with St. Cyprian, but it is possible to test the passages by an indrrect method.

Primasius, in his commentary on the Apocalypse, states that Tyconius the Donatist (from whose work he borrowed much of his material) commented upon a different version from that which he used himself ${ }^{3}$.

'De Errore Prof. Relig. c. 28.

'In Apoc. xix ${ }^{3} 3$ the reading 'sermo de1' is found in Test. ii 3, while in Test. in 30 the reading is 'uerbum dei.' In Ad Fortunat. I I Hartel reads 'in conspectu honons dei' in Apoc. vil ${ }_{5}$, following $\mathrm{S}$ against $\mathrm{W} \mathrm{R} v$, which have 'in conspectu throni dei.' This latter is Hartel's reading in the parallel passage (Test. iii 16) where $B$ has yet another variant 'ante sedem.' 'In conspectu throni del ' appears to be the true reading in both passages. $\quad{ }^{3}$ Cf. Primasıus on Apoc. ix 16. 
Dr. Haussleiter some years ago emphasized the importance of putting together, from Primasius, Pseudo-Augustine, Beatus, and other writers who have used Tyconius, such portions of his version as could be Identified ${ }^{1}$. Since that time Dom Amelli, of Monte Cassıno, has printed from a Turin MS ${ }^{2}$ considerable portions of a commentary on the Apocalypse, which he believes to be that of Tyconius himself. If this identification is not free from difficulties, at least the fragments contain much of Tyconius's matter, and from them, together with the other available sources, especially Beatus, it is possible to obtain a fair knowledge of the version upon which the commentary was based. Thus we have two types of Apocalyptic text, one represented by Primasius, the other by Tyconius. Using these as standards of comparison, we find that while the undoubted Cyprianic citations agree closely with the version of Primasius, the citations contained in the insertions approximate rather to the type of text used by Tyconius.

We may, then, regard it as certain that the Apocalyptic citations in the inserted pieces are not taken from St. Cyprian's version. It is curious that Mercati, who alludes to this fact at the beginning of his book ${ }^{3}$, leaves it entrrely out of consideration when he comes to discuss the insertion(s) more at length in Appendix A. And yet if the nonCyprianic character of the Apocalyptic citations be admitted, and if it be admitted that all the insertions were made by one hand, the conclusion is inevitable that St. Cyprian bad nothing to do with any of them.

2. But evidence is not wanting that the version of the Prophets used by the interpolator, though doubtless related to that used by St. Cyprian, was by no means identical with it. It is the more important to inquire into this point, because Mercati has expressed his belief in the substantial identity of the two versions ${ }^{4}$.

Here again we have opportunities of direct comparison.

Jer. $11 . \quad 3$ is a convenient starting-point, as it is quoted no less than three times by St. Cyprian, as well as in the interpolation in Test. ii 59.

1 Forschungen sur Geschichte des neutestamentlichen Kanons iv, ed. Haussleiter and Zahn, pp. 77,78 , and an article in the Zetschnft für kinchliche Wissenschaft, I 886, pp. 239-257. I am not sure that it is safe to assume, as Dr. Haussletter does (Forschungen, pp. 69 and 77 ), that all the alternative renderings which Primasius mentions are taken from the version used by Tyconius.

2 Cod. Taurinensis F. iv. I (olım Bobıensis n. 62). The MS contains the comments on Apoc. 11 I8-1V I, v11 16-xii 6. These are printed in the Spralegium Casinense, T. iii (1897). Hahn, in his recent Tyconius-Studien, pp. vl, vil, 14, I5, holds that in these fragments the matter of Tyconius has been much modified, and that Beatus is still our chuef authority for the Commentary in its onginal form. With this vew Prof. Bousset appears to agree.

\footnotetext{
3. 3 .

'p. 63 .
} 
Jer. il 13 .

Ep. 70, 1, p. 767, 10. De Unit. I 1, p. 219 , 16.

$\begin{array}{cc}\begin{array}{c}\text { Me dereliquerunt } \\ \text { fontem aquae }\end{array} & \begin{array}{c}\text { Me dereliquerunt } \\ \text { fontem aquae }\end{array} \\ \text { uitae }{ }^{\mathbf{1}} ; & \text { uitae }{ }^{\text {; }} \\ \text { et effoderunt } & \text { et effoderunt } \\ \text { sibi lacus } & \text { sibi lacus } \\ \text { detritos } & \text { detritos } \\ \text { qui non possunt } & \text { qui non possunt } \\ \text { aquam } & \text { aquam } \\ \text { portare. } & \text { portare. }\end{array}$

1 uitae C c L P V, ' uitae W G V, uiuae $c^{2} \mathrm{R}$ in ras, uiuae $\mathrm{R} M$. uluae gratıs $Q$.
Test. 13, p. $41,8$.
Me derelıquerunt fontem aquae uiuae ${ }^{1}$; et ${ }^{2}$ effoderunt sibi lacus detritos $^{3}$ qui non poterunt aquam portare.

1 uitae V.

2 et] om. A.

som. A.
Test. iii 59 (insertion), p. $161,20$.

Dereliquerunt me fontem aquae uiuae et foderunt 1 sibi lacus contritos $^{2}$ qui non poterant aquam continere.

1 effoderunt $v$.

2 detritos $v$.

This passage is not without textual difficulty : it would be a familiar one to scribes, and the difference in external form between 'uitae' and "uiuae"' is so slight that it is not surprising to find a confusion between the two words in all the genuine places; but it is fairly clear that 'utae' was the Cyprianic reading, and that $\mathrm{V}$ is right in giving it in Test. $\mathrm{i}_{3}$; it is worth noting, too, that the Wurzburg MS itself has ' uitae' in De Unit. I I, where $M$ in Hartel's note is a misprint for W. But the test-word is 'continere.' That word (which is the Vulgate reading) was used in Africa before St. Cyprian's time in (Tert.) $A d v$. Iud. I3, and after it by Optatus (iv 9), but it is not the word of St. Cyprian's version.

The next passage is Jer. $x 2$ :-

Test. iii 34, p. 146, 20.

Haec dicit Dominus, Secundum uias $^{1}$ gentium ${ }^{2}$ ne ambulaueritis ${ }^{3}$.
Test. iii 59 (insertion), p. $161,8$.

Haec dicit Dominus, Secundum uias gentium nolite incedere.

1 uiam M Bv.

2 gentılium L M $v$.

abieritis $\mathrm{B}$.

Even in this short verse there is a characteristic difference of translation, a difference lying beyond the ordinary accidents of textual transmission.

The above passages (occurring in Test. ii 59) are not noticed by Mercati to the quotation from Jer. xxxi, which has a special interest for him as occurring in the Quirinian fragment (Test. 1ii 20), he gives a good deal of attention. Before examining it, it will be well to state how far we have material for comparison. The continuous passage

1 The two words, of course, correspond to divergent readings in the LXX, where

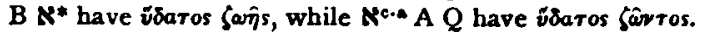


Jer. xxxi 31-34 ('Ecce dies ueniunt ... . memor amplius') forms part of the long insertion in Test. iii 20 . The same passage is found in Test. i I r, but there only the first part ('Ecce dies ueniunt . . . . de terra Aegypti' $\left.=v v \cdot 3^{1}, 3^{2} \mathrm{a}\right)$ is common to all the MSS; the rest is omitted by all Hartel's MSS (W does not contain Test. i I-r 5 ), and is printed by him in square brackets, apparently from the text of previous editors. It is not my purpose to discuss the genuineness of the addition in Test. i $\mathrm{I}$, which belongs, as I shall show presently, to a different class of insertions from those which form the subject of this note. It will be sufficient to point out that when Mercati, in defence of the passage, urges the a priori improbability that St. Cyprian would have broken off his quotation at the words 'de terra Aegypti,' he forgets that Tertullian who twice quotes the passage in his work against Marcion (i 20 , iv I ) ${ }^{1}$ on both occasions stops at this place, and that three times at least St. Augustine does the same ${ }^{2}$.

In view of the strong presumption which is raised against the genuineness of the addition in Test. i I I by the fact of its absence from the best MSS, I will compare only the generally attested part of the passage in Test. i I $\mathrm{I}$ with the corresponding part of the interpolation in Test. iii 20.

Jer. $x x x i \quad 3 \mathbf{I}-3^{2}$.

Test. i I I, p. 46, 19.

Ecce dies ueniunt ${ }^{1}$, dıcit Dominus, et consummabo domui ${ }^{2}$ Israel et domui ${ }^{3}$ Iuda testamentum nouum, non secundum testamentum quod disposui patrıbus eorum in ${ }^{4}$ die qua adprehendi manus eorum ut educerem $\cos ^{5}$ de terra Aegypti.

1 ueniunt ex venient $M$.

domum L M B.

domum $\mathrm{M}$ B.

- in om. B.

eos om. V.
Test. ii 20 (insertion), p. $134,18$.

Ecce dies ueniunt, dıcit Dominus, et consummabo in domum ${ }^{1}$ Israel et in domum ${ }^{2}$ Iuda testamentum nouum, non secundum testamentum quod disposueram patribus eorum in die cum adprehendi manum illorum educere

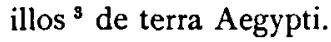

I super domum $v$.

in domo $v$.

$\cos v$.

If the two presentments of the passage have a common background, there are greater differences than we should expect to find in an author who quotes so carefully as St. Cyprian. Mercati acknowledges the

1 The citation in $A d v$. Iud. 3 also terminates at that point.

- Serm xxv I; Op. Imperf. contr. Iul. lib. 3, cap. 84; De Gestzs Pelagii 5 i4. In the two latter places the text agrees precisely with that of Hartel in Test i i i except that St. Aug. has 'manum' instead of 'manus.' In De Spur tt Ltt. $\$ 3 j$ St. Aug. quotes to the end of ver. 34 , and with a different text. 
differences, but, taking the bull by the horns, maintains that the Cyprianic version is better preserved in the interpolation than in the undisputed passage.

As to the first variant, it is no doubt true that Hartel's reading (in Test. i I1) 'domui . . . . domui ' cannot be regarded as certain, but it has much to recommend it, and there is, as far as I can see, no reason whatever for supposing that the alternative reading 'domum .... domum' ( $\mathrm{L}$ apparently has 'domum . . . . domui') is a mutilated relic of the reading ' 1 domum . . . . in domum,' which is found in the interpolation in Test. iii 20, and, I belseve, nowhere else. Yet Mercati states this as a fact.

In like manner he doubts whether 'in die qua' can compete with 'in die cum,' 'che nella stessa rarità e forse volgarità della sua forma porta l' impronta della genuinità.' And yet 'in die qua' is found in all the MSS of St. Cyprian in Test. i $\mathrm{I}$ as well as in Lactantuus (Instt. iv 20) who seems to have taken the quotation from the Testimonia.

Finally Mercatı tells us that Quir. and $\mathrm{W}$ in the interpolation (Test. iii 20) are 'più integri,' i. e. presumably, have kept the Cyprianic text better than all the MSS, even the best, in Test. i I I, "dove " educere Illos" fu mutato nella lezione della Volgata "ut educerem eos." There is not a shadow of evidence that the reading of the MSS is incorrect, or that the final infinitive is specially characterıstic of St. Cyprian's version; on the contrary, in Apoc. xiv 6 it is the interpolator (p. 136, 2) who has the final infinitive 'euangehzare' while St. Cyprian has 'ut adnuntiaret' (p. 323, 4).

Thus in the case of the Prophets, as well as of the Apocalypse, wherever we are able to place the text of the interpolations side by side with an undoubtedly genuine citation of the same passage ${ }^{1}$, we find discrepancies which point to a difference of origin.

For the remaining citations from the Prophets the only available test is that of characteristic renderings. The test is a fair one, but it can only lead to reliable results when applied on a large scale. A complete analysis of the language of these citations cannot be attempted here; but since Mercati (p. 63) mentions five characteristic translations as being sufficient, when taken in connexion with other minor peculiarities not specified, to prove the substantial identity of the version of the prophets used by the interpolator with that used by St. Cyprian, I have thought it desirable to examine all the places in the Cyprianic quotations from the prophets in which translations of the five Greek words

${ }^{1}$ Mal. it 5 , which occurs in the interpolation in Test. in 20 , is also quoted in Test. 115 , and with only one slight variation, but the citation is omitted in Test. i1 5 in L B V Benev. and many other MSS, and therefore lies under suspicion of being a post-Cyprianic addition in that place also. 


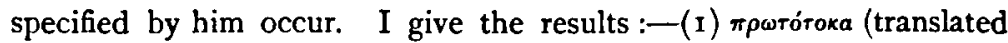
by 'primitiva,' p. I37, I9) does not occur in the LXX of any (other) Cyprianic quotation from the prophets. (2) imırı $\theta$ íva (translated by 'superponere,' p. 138,4) occurs in one other place (p. 78, 23), and there the rendering is 'imponere ... super.' (3) í $\psi$. $\sigma$ ros (translated by 'sublimis,' p. 137, I 7) occurs in one other place (p. 669, 16), and there the Cyprianic equivalent is 'altissimus.' It is difficult to see why this word was included in the list, as Mercati admits that St. Cyprian's ordinary translation is 'altissimus.' (4) The translation of $\lambda$ aós by 'plebs' (p. 135,5 and $14 ;$ p. $138,19, \&$ c.) is by no means characteristic of St. Cyprian's version of the prophets. In undoubtedly genuine quotations $\lambda a o_{\text {s }}$ is represented by 'populus' twenty-three times, by 'plebs' six tımes ; in doubtful passages 'plebs' is found five times, 'populus' twice. (5) The translation of 'is by 'quomodo' in the sense of 'sicut' (p. 138,6 ) is certainly not Cyprianic in the prophets : out of some forty cases in which ws in this sense occurs in the LXX of St. Cyprian's quotations I have not found one in which the word is represented by 'quomodo.' Thus none of the five renderings can be shown to be characteristic of St. Cyprian's version of the prophets; and some of them go to strengthen the argument against a Cyprianic origin of the insertions.

3. The witness of the formulae of citation tells in the same direction. Mercati recognuses the significance of slight differences in these formulae as affording a test of genuineness, but he seems to think that the $W$ additions have nothing to fear from the application of this test,- ' per le formule introduttorie pochi dubbi restano '. But here again I am compelled to differ from hım. It can, I think, scarcely be accidental that the formula of quotation from the prophets, which is consistently used in the interpolations (eleven times in all ${ }^{2}$ ), is different from that which (perhaps with not a single exception ${ }^{3}$ ) is regularly found throughout the Testimonia in the best MSS, including W. The

${ }^{1}$ p. 67.

'I do not count 'In Baruch' (Test. iii 29', as that may be considered to stand on a different footing In one case out of the eleven (p. 134, 17), Baluze has 'Apud Hieremiam,' but 'In Hieremia' is supported by $W$ and the Qunnian fragment.

3 All Hartel's authorities appear to have 'In Osee' in Test. ui I (p. 110, 18 ), but even there Manutius and Fell print 'Apud Osee.' [A MS of St. Cyprian in the library of Lord Crawford has 'De hoc ipso aput Osae.'] W $\mathrm{M} \mathrm{L}^{2}$ followed by Hartel have 'In Daniele' [-0] on p. 151,2 , but there again the true reading is that of A B L' [and the Crawford MS] 'In Machabeis,' and the citation, being taken from an histoncal book, has no bearing on the point under consideration. $M$ has the prep. 'In' in one other place p. 89, 3), and $A$ in seven (p. 5., I I and I5; p. I I , 2 and $13 ;$ p. 144,3 ; p. 156,$18 ;$ p. 164,20 ). 'In' 15 also found before the doubtful quotation of Mal. $1 \mathrm{i} 5$ in Test. 1 i 5 . 
formula of the interpolator is 'In Hieremia,' \&c. ; that of St. Cyprian is 'Apud Hieremiam.'

Thus all the evidence converges irresistibly to the conclusion that these insertions, though worthy of being edited for the sake of therr Biblical text, are not Cyprianic, and are, therefore, not entitled to a place in the text of the Testimonia.

Before concluding it may be well to clear up a matter about which there appears to be some confusion.

At the beginning of his book Mercati enumerates the additions to Test. $\mathrm{i}$ I, I I, I3, I4 as belonging to the series characteristic of $\mathrm{W}$. This is an error. Test. $\mathbf{i} \mathbf{I}-\mathbf{I} 5$ are not preserved in $\mathrm{W}$ at all, so that we cannot say whether the preces in question were in that MS or not; but there is direct evidence that they do not belong to the series which forms the subject of this note:-(I) The history of their transmission is different : though absent from most of the MSS (from all those used by Hartel) they have a much wider diffusion than the interpolations in Test. iii, and found their way very early into the printed editions. (2) There are considerable differences between the text of Jer. xxxi 32-34 as given in Test. $\mathrm{i} I \mathrm{I}$ and in Test. iii 20 : in the former place we find 'neglexi eos' and 'dinosce,' in the latter 'neglexi eorum' and 'cognosce'; in Test. i $\mathrm{II}$ the words 'et in corda illorum' are omitted '; and again in Test. iii $20 \mathrm{~W}$ and Quir. agree in the curious reading 'et docebunt,' while in $i \mathrm{x}$ the ordinary reading 'et non docebunt' is found. (3) Finally the form of quotation from the prophets which $I$ have shown to be characteristic of the $W$ interpolations, is not used in the additions to Book i.

H. I. Ramsay.

\section{ON THE DATE OF COMPOSITION OF THE PASCHAL CHRONICLE.}

THE Paschal Chronicle, otherwise called the Alexandrine or Constantinople Chronicle or the Fasti Siculi, consists of a tabular chronology with historical notices extending from Adam to 627 A.D. The Olympiads and consular lists are added in the text, and later on the Indictions. The compiler derives his matter from various sources, e.g., the Bible, Sextus Julus Africanus, Eusebius, Idatius (Hydatius in Mommsen's spelling), Epiphanius, Pseudo-Kallisthenes, Malalas, Acts of Martyrs. The whole work, as it is found in the best codex, Vaticanus Gr. 1941,

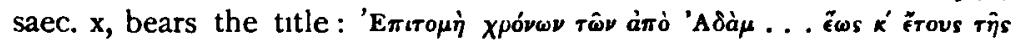

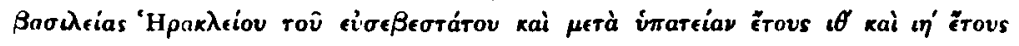

1 Mercati erroneously enumerates this omission as one of the imperfections of $W$ in il 20. W has the words there. 